\title{
An Empirical Study of Comprehensive Ladder Task Chain Model in Independent Colleges' Business English Writing Course
}

\author{
Liaoliao ZHANG ${ }^{1,2}$ \\ ${ }^{1}$ Huaxia Institute of Technology, Wuhan, 430223, China \\ ${ }^{2}$ Wuhan University of Technology Huaxia College, Wuhan, 430223, China \\ email: 164073893@qq.com
}

Key word: Comprehensive; Ladder Task Chain; Independent College; Business English Writing

\begin{abstract}
The author in this paper makes a practical exploration and improvement of pre-task and task circle on the basis of Williams' task-based teaching model. According to the course characteristics of business English writing and the English proficiency of students in independent college, the author proposes the comprehensive ladder task chain model and conducts an empirical study. The study shows that this model has more positive effect on arousing students' interest in business English writing and thus can promote students' business writing ability more effectively.
\end{abstract}

\section{Introduction}

Business English writing aims at cultivating students' ability and skills to use written English to communicate in business environment so as to realize business goal. This course cultivates not only students' language proficiency, but also their comprehensive ability to be engaged in foreign economic activities. [1] However, the 3P teaching model adopted in this course has severely lagged. This class should be organized under the real business circumstances where the teacher inputs some language knowledge and business knowledge and get students to pay more attention to meaning-centered activities and promote students' effective output through the completion of activities and tasks. [2] The task-based teaching model proposed by Williams has stronger practical significance and feasibility. It involves three steps: (1) pre-task, namely the preparatory stage of task design where topic and task is introduced to provide language environment for the task ;(2) while-task stage where learning motivation is aroused by the completion of task. This stage includes task, plan, and report. (3) language-focus stage where analysis and exercise are done. Does this model suit the students of different levels? Does it suit all language class? How does "task" and "task complexity" and "task order" and other items are displayed in this model?

\section{The comprehensive task chain model}

The raising of comprehensive task chain model

Before the study, the researcher analyzed the errors in two pieces of writing from the two classes in our department, since students of independent college are quite weak in English grammar, language structure, business discourse, business knowledge and so on. Is Williams' model applicable to the business English writing class in independent college? Can it enhance students' business English writing ability? How should the teacher design and choose task so as to make the task pragmatically, contextually and semantically authentic? How to make the task interesting, communicative, scientific and extensible? How to constantly innovate the task form and adjust its difficulty to make it a mode from simplicity to complexity, from easiness to difficulty and from elementary to advance? After many years of front-line teaching, the author in this paper makes a practical exploration and improvement of pre-task and task circle on the basis of Williams' task-based teaching model. According to the course characteristics of business English wring and the English proficiency of students in independent college, the author proposes the comprehensive ladder task chain model and elaborates how to use this model to design business English writing 
and how to make empirical study?

The comprehensive ladder task chain model

This model, which stresses comprehensiveness and ladder chain model, is based on constructivism theory of learning. It solves teachers' problem of randomly sequencing and selecting the task. Comprehensiveness, which stresses the width and intensity of task, means that the teacher adopts different forms of task organization (material reading, literature search and discussion, group discussion, investigation and research, dialogue between teacher and students, summary report, etc) in designing the task (basic task, core task, development duty, etc.). [3] The comprehensiveness varies with the difficulty of task. Elementary knowledge, basic skill, difficulty, core skill and teaching aim are unified by different tasks. In the comprehensive model, students actively develop independent, exploratory and cooperative learning through completing various tasks. Another key word is ladder task chain. What the ladder task chain model shows is hierarchy and level of difficulty. It divides the subject or the unit of study into closely related and well-ordered tasks. The principle for task design is from easiness to difficulty, from basic task to core task and then to extensible task. The link of each hierarchical task forms the task chain. The business English writing is based on the framework of international business procedure where the teaching units have close relationship. The understanding and extension of each unit is based on the previous unit and thus shows the characteristics of ladder. [4] The completion of one task chain is marked by participants' successful completion of all tasks and this experience can provide experience and lesson for the next task chain and thus makes the teaching activities deepened. The author combines the comprehensiveness and ladder task chain so that each unit forms the comprehensive ladder task chain model in which knowledge structure of each unit is based and organized from the shallower to the deeper. The task chain can be chosen and adjusted according to the acceptance level of students, thus the business English teaching model which shows special feature and can satisfy the needs of independent students is formed.,

\section{Empirical study}

\section{A. Research design}

a. research question: 1) is the comprehensive ladder task chain model more suitable for enhancing students' business English writing ability as compared with the 3P model? 2) Does students' business English situation change before and after the survey? 3) Students' attitude to the comprehensive ladder task chain model.

b. Research methodology: a combination of quantitative method (pre-test and after-test) and also the qualitative method (interview and questionnaire survey).

c. Objects of the study

Two classes of business English majors in their third grade from an independent college in Wuhan were chosen (Class 1 with a total number of 35 people, Class 2 with 31 people) and totally there are 66 students for this study. The experiment chooses Class 1 as experimental class and Class 2 as control class. Two classes are completely the same in lesson, teacher and teaching environment and so on.

\section{d. Study tools}

Pre-test, after-test, questionnaire and interview are included. Mean and standard deviation is also involved. Independent sample T-test is used in group comparison and paired sample t-test in the intra-group comparison. The SPSS 21.0 statistical software is adopted to complete the analysis.

B. Research process

a. Pre-test

Before the test, the two classes have already finished part of the business English class in the first semester of grade three: Cambridge Business English and Business Etiquette. The pre-task is done within 30 minutes in the first week with a total score of 20 points. The writing grading standard for the International Business English Test Level $\mathbb{I}$ is adopted to increases the credibility of grading. Independent sample t- test statistical result (Table1) demonstrates that for the total score (Class 1 with an average score of $(13.31 \pm 1.28$, Class 2 with an average score of 
13.32 $\pm 1.47, \mathrm{P}=0.981$ ), the two classes have no statistical significance in the pre-test result.

Table 1

\begin{tabular}{|c|c|c|c|c|}
\hline index & Class 1（N=35） & Class 2 $(\mathrm{N}=31)$ & $\mathbf{T}$ & $\overline{\mathbf{P}}$ \\
\hline $\begin{array}{ll}\text { total } & \\
& \text { Pre-test }\end{array}$ & $13.31 \pm 1.28$ & $13.32 \pm 1.47$ & -0.02 & 0.981 \\
\hline
\end{tabular}

The control class adopts the 3P model to organize class while the experimental class uses the comprehensive ladder task chain model to organize class. The teaching of the experimental class and control class is all undertaken by the researcher. The 3P model focuses on the teacher's demonstration of model essay and writing techniques and students' drill is secondary and the last step is the demonstration of writing achievement and teacher's comments. In The comprehensive ladder task chain model, each unit forms the teaching model in which the knowledge structure of each unit is focused and lectured from the shallower to the deeper, as is shown in the following

Flow Chart 1

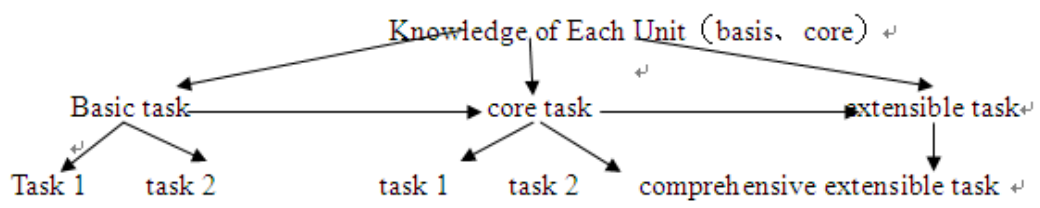

Take the offer and counter-offer in the unit 4 as an example. The core knowledge of this unit is the writing, structure, key sentences and important expressions in offer letter and counter-offer letter. The teaching aim is to enable students to independently write related letter and translate business letter. There are 7 periods for this unit.

Bask task 1: pre-task: The teacher lecturers the definition, classification and characteristics of offer and also the definition of counter-offer and counter-counter offer. Students work with their desk mates to explain the definition of offer and counter-offer and also express their understanding on the basis of the lecturing in English. They need to combine the previous knowledge to explain the business process from establishing business relations, inquiry, offer and replies to counter-offer. In the while-task stage, there is conversation between the teacher and students within limited time. The teacher ask questions and the students express their understanding. In the after-task, students need to search materials and summarize the rule of counter-counter offer.

Basic task 2: pre-task: The teacher provides several pieces of reading materials about offer letter and counter-offer letter. The experimental class is divided into 5 groups, each with a member of 6-7 students. Students work in groups to discuss, analyze and summarize the writing procedures of offer letter and counter-offer letter and then put it into writing. Each procedure is supported with 5-6 key sentences. Also, key structure, expressions and vocabulary needs to be found. In the while-task, each group needs to send a representative to report. Other students need to listen carefully and think carefully and take notes. After the report, the teachers ask questions and make comments and analyze the most reasonable writing step. In the after-task, there are sentences translation and business letter translation. In extensible exercisers, key sentences pattern needs to be found out and memorized.

Core task 1: Pre-task: The experimental class is divided into 6 groups, each group with a member of 5-6 students. 3 groups act as of Export Company and the other 3 groups act as Import Company. Each group has a team leader, a recorder and a reporter. The export company discuss the establishment and the main export products of the company and also the advantage of the product referring to what the teacher has given (characteristics; advantage; innovation and function; suitable groups; product price; way of payment, etc.). Students can refer to shell button price list to discuss and determine the price of export products and then discuss and write offer letter. The import company is responsible for establishing company. In the while-task, the reporter introduces the company established and shows the offer letter. In the after-task, the teacher analyzes comments and gives marks. In view of the comments, students need to improve it.

Core task 2: pre-task: based on the grouping in the core task 1, the import company writes counter-offer letter as reply to the offer letter of Export Company. (If the offer letter of export 
company in task 1 does not manifest the characteristics of the product or the import company is not interested in this offer letter compared with offer letters from other groups, this task fails in winning potential customer.) In while-task, the reporter introduces the import company established and also show the counter-offer letter of chosen export company and gives counter-offer conditions. In after-task, the teacher analyzes comments and gives marks. In view of the comments, the students improve it again. In view of the comments, the import company revises it once more. In the extensible exercise, export company makes reply.

Comprehensive and extensible task: the writing of business plan, offer letter and counter-offer letter for an e-commerce company (import-export company) featuring Hubei products. 1) Business plan. 2) Demonstrating the company and creating PPT. 3) export company submits the latest quotation and writes the offer letter. 4) the import company makes a reply.

\section{c. After-test}

After 10 weeks of teaching, the two classes receive the after-test at the same place and the same time. They are required to finish a promotion letter in 30 minutes. Scale of marks is the same to that of the pre-test, namely, the total score is 20 points, with a distribution of 5 points in the organization, language, content, format and business knowledge respectively. According to statistics table 2, for the after-test writing in the experimental class, the difference in the total score $(\mathrm{P}=0.000$; an average score of $15.57 \pm 1.12)$, organization $(\mathrm{P}=0.001$; an average score of $3.89 \pm 0.40)$, language $(\mathrm{P}=0.000$; an average score of $3.77 \pm 0.49)$, content $(\mathrm{P}=0.000$, an average score of $3.83 \pm 0.45)$, format and business knowledge $(\mathrm{P}=0.005$, an average sore of $4.09 \pm 0.45)$ has statistical significance and they all have made remarkable improvement. The T-test of paired sample in the experimental class shows significant difference $(\mathrm{P}=0.001)$. The statistical result shows the comparative difference in the pre-test and after-test for the experimental class has statistical significance and the after-test has better results than the pre-test. Also, the statistical result shows that the difference between the result of control class in the pre-test and after-test as compared with format and business knowledge and total has statistical significance. For other difference, there is no statistical significance. Thus, we can draw the conclusion that the comprehensive ladder task chain model can raise students' business English writing level more effectively.

\begin{tabular}{|c|c|c|c|c|c|c|}
\hline Index & class 1 ( & & Class 2( & & $\bar{T}$ & $\overline{\mathbf{P}}$ \\
\hline \multicolumn{7}{|l|}{ organization } \\
\hline Pre-test & \multicolumn{2}{|c|}{$3.46 \pm 0.56$} & \multicolumn{2}{|c|}{$3.42 \pm 0.62$} & 0.26 & 0.796 \\
\hline Post-test & \multicolumn{2}{|c|}{$3.89 \pm 0.40$} & \multicolumn{2}{|c|}{$3.45 \pm 0.57$} & 3.61 & 0.001 \\
\hline paired T-test & -4.55 & 0.000 & -0.57 & 0.572 & & \\
\hline language & & & & & & \\
\hline Pre-test & \multicolumn{2}{|c|}{$3.17 \pm 0.38$} & \multicolumn{2}{|c|}{$3.06 \pm 0.36$} & 1.17 & 0.248 \\
\hline Post-test & \multicolumn{2}{|c|}{$3.77 \pm 0.49$} & \multicolumn{2}{|c|}{$3.16 \pm 0.37$} & 5.63 & 0.000 \\
\hline paired T-test & -6.42 & 0.000 & -1.79 & 0.083 & & \\
\hline \multicolumn{7}{|l|}{ Content } \\
\hline Pre-test & \multirow{2}{*}{\multicolumn{2}{|c|}{$\begin{array}{l}3.40 \pm 0.55 \\
3.83 \pm 0.45\end{array}$}} & \multicolumn{2}{|c|}{$\begin{array}{l}3.26 \pm 0.58 \\
3.32 \pm 0.54\end{array}$} & 1.02 & 0.311 \\
\hline Post-test & & & & & 4.14 & 0.000 \\
\hline paired T-test & -5.05 & 0.000 & -1.00 & 0.325 & & \\
\hline \multicolumn{7}{|c|}{ format and business knowledge } \\
\hline Pre-test & \multirow{2}{*}{\multicolumn{2}{|c|}{$\begin{array}{l}3.29 \pm 0.57 \\
4.09 \pm 0.45\end{array}$}} & \multirow{2}{*}{\multicolumn{2}{|c|}{$\begin{array}{l}3.55 \pm 0.51 \\
3.77 \pm 0.43\end{array}$}} & -1.96 & 0.054 \\
\hline Post-test & & & & & 2.90 & 0.005 \\
\hline \multirow{2}{*}{\multicolumn{7}{|c|}{ Total }} \\
\hline & & & & & & \\
\hline Pre-test & \multicolumn{2}{|c|}{$\begin{array}{l}13.31 \pm 1.28 \\
15.57 \pm 1.12\end{array}$} & \multicolumn{2}{|c|}{$13.32 \pm 1.47$} & -0.02 & 0.981 \\
\hline Post-test & & & & & 6.20 & 0.000 \\
\hline paired T-test & -16.35 & 0.000 & -2.83 & 0.008 & & \\
\hline
\end{tabular}

d. Questionnaire survey

The questionnaire survey with the same content is conducted twice to investigate the learning situation in business English writing class. The first questionnaire survey is conducted in two classes before the start of the project and the second one is conducted only in experimental class after the end of the project. The survey includes: learning motivation for business English writing; learning interest and confidence in business English writing; business English writing ability. The experimental class has 34 effective questionnaires for the pre-test questionnaire and the control class has 31. According to Table 3, the students don’t have strong learning motivation and lack 
confidence and interest in learning before the pre-test, thus we are not sure whether their learning ability can be enhanced.

Table 3

\begin{tabular}{|c|c|c|c|c|c|}
\hline questionnaire & $\begin{array}{l}\text { Strongly } \\
\text { disagree }\end{array}$ & disagree & $\begin{array}{l}\text { Neither agree nor } \\
\text { disagree }\end{array}$ & agree & Strongly agree \\
\hline & \multicolumn{5}{|c|}{ 1. I have a strong willingness of learning Business English Writing. } \\
\hline experimental class & $3 \%$ & $8.8 \%$ & $55.9 \%$ & $20.6 \%$ & $11.8 \%$ \\
\hline control class & $6.5 \%$ & $12.9 \%$ & $54.8 \%$ & $19.4 \%$ & $6.5 \%$ \\
\hline & \multicolumn{5}{|c|}{ 2. I think Business English writing ability is very important and useful. } \\
\hline experimental class & $0 \%$ & $5.9 \%$ & $50 \%$ & $29.4 \%$ & $14.7 \%$ \\
\hline control class & $0 \%$ & $12.9 \%$ & $41.9 \%$ & $35.5 \%$ & $9.7 \%$ \\
\hline & \multicolumn{5}{|c|}{ 3. The activities in Business English Writing class are close to real business situations. } \\
\hline experimental class & $3 \%$ & $14.7 \%$ & $52.9 \%$ & $23.5 \%$ & $6 \%$ \\
\hline control class & $0 \%$ & $19.4 \%$ & $51.6 \%$ & $25.8 \%$ & $3.2 \%$ \\
\hline & \multicolumn{5}{|c|}{ 4. In Business English Writing class, I can discuss interesting matters with favorable partners. } \\
\hline experimental class & $0 \%$ & $26.5 \%$ & $52.9 \%$ & $17.6 \%$ & $3 \%$ \\
\hline control class & $0 \%$ & $25.8 \%$ & $51.6 \%$ & $16.1 \%$ & $6.5 \%$ \\
\hline & \multicolumn{5}{|c|}{ 5. I think I can succeed in achieving the goals of the Business English Writing tasks. } \\
\hline experimental class & $0 \%$ & $29.4 \%$ & $41.2 \%$ & $20.6 \%$ & $8.8 \%$ \\
\hline control class & $0 \%$ & $38.7 \%$ & $45.2 \%$ & $12.9 \%$ & $3.2 \%$ \\
\hline & \multicolumn{5}{|c|}{ 6. I am very interested in Business English Writing course rather than only pass examination. } \\
\hline experimental class & $0 \%$ & $23.5 \%$ & $50 \%$ & $14.7 \%$ & 11.8 \\
\hline control class & $0 \%$ & $12.9 \%$ & $54.8 \%$ & $22.6 \%$ & $9.7 \%$ \\
\hline & \multicolumn{5}{|c|}{ 7. I am very confident in my Business English Writing ability. } \\
\hline experimental class & $0 \%$ & $50 \%$ & $29.4 \%$ & $20.6 \%$ & $0 \%$ \\
\hline control class & $0 \%$ & $29 \%$ & $45.2 \%$ & $25.8 \%$ & $0 \%$ \\
\hline & \multicolumn{5}{|c|}{$\begin{array}{l}\text { 8. In Business English Writing class, I have enough material and know how to organize a } \\
\text { composition by exchanging ideas with my classmates. }\end{array}$} \\
\hline experimental class & $0 \%$ & $23.5 \%$ & $61.8 \%$ & $14.7 \%$ & $0 \%$ \\
\hline control class & $0 \%$ & $35.5 \%$ & $54.9 \%$ & $9.7 \%$ & $0 \%$ \\
\hline & \multicolumn{5}{|c|}{ 9. I think the writing approach the teacher used is very interesting. } \\
\hline experimental class & $0 \%$ & $8.8 \%$ & $47.1 \%$ & $29.4 \%$ & $14.7 \%$ \\
\hline control class & $0 \%$ & $19.4 \%$ & $51.6 \%$ & $22.6 \%$ & $6.5 \%$ \\
\hline & \multicolumn{5}{|c|}{ 10. I think I can improve my Business English Writing abilities gradually. } \\
\hline experimental class & $0 \%$ & $11.8 \%$ & $47.1 \%$ & $29.4 \%$ & $11.8 \%$ \\
\hline control class & $0 \%$ & $6.5 \%$ & $58.1 \%$ & $25.8 \%$ & $9.7 \%$ \\
\hline & \multicolumn{5}{|c|}{ 11. I think the writing approach that the teacher is taking can improve my creative ability. } \\
\hline experimental class & $0 \%$ & $32.4 \%$ & $47.1 \%$ & $14.7 \%$ & $5.9 \%$ \\
\hline control class & $0 \%$ & $41.9 \%$ & $41.9 \%$ & $12.9 \%$ & $3.2 \%$ \\
\hline & \multicolumn{5}{|c|}{ 12. I think the writing approach that the teacher is taking can improve my investigation ability. } \\
\hline experimental class & $3 \%$ & $0 \%$ & $61.8 \%$ & $32.4 \%$ & $3 \%$ \\
\hline control class & $3.2 \%$ & $12.9 \%$ & $54.8 \%$ & $25.8 \%$ & $3.2 \%$ \\
\hline
\end{tabular}

After the experiment, questionnaire survey is conducted again in the experimental class (34 effective questionnaires) and the result indicates that students' learning motivation, learning interest and learning confidence are strengthened; therefore, their writing ability is enhanced. (Table 4) 
Table 4

\begin{tabular}{|c|c|c|c|c|c|}
\hline questionnaire & $\begin{array}{l}\text { Strongly } \\
\text { disagree }\end{array}$ & disagree & $\begin{array}{c}\text { Neither agree } \\
\text { nor disagree }\end{array}$ & agree & Strongly agree \\
\hline & \multicolumn{5}{|c|}{ 1. I have a strong willingness of learning Business English Writing. } \\
\hline \multirow[t]{2}{*}{ experimental class } & $0 \%$ & $2.9 \%$ & $14.7 \%$ & $55.9 \%$ & $26.5 \%$ \\
\hline & \multicolumn{5}{|c|}{ 2. I think Business English writing ability is very important and useful. } \\
\hline \multirow[t]{2}{*}{ experimental class } & $0 \%$ & $2.9 \%$ & $5.9 \%$ & $47.1 \%$ & $44.1 \%$ \\
\hline & \multicolumn{5}{|c|}{ 3. The activities in Business English Writing class are close to real business situations. } \\
\hline \multirow[t]{2}{*}{ experimental class } & $0 \%$ & $2.9 \%$ & $2.9 \%$ & $53 \%$ & $41.2 \%$ \\
\hline & \multicolumn{5}{|c|}{ 4. In Business English Writing class, I can discuss interesting matters with favorable partners. } \\
\hline \multirow[t]{2}{*}{ experimental class } & $0 \%$ & $5.9 \%$ & $14.7 \%$ & $35.3 \%$ & $44.1 \%$ \\
\hline & \multicolumn{5}{|c|}{ 5. I think I can succeed in achieving the goals of the Business English Writing tasks. } \\
\hline \multirow[t]{2}{*}{ experimental class } & $0 \%$ & $8.8 \%$ & $14.7 \%$ & $52.9 \%$ & $23.5 \%$ \\
\hline & \multicolumn{5}{|c|}{ 6. I am very interested in Business English Writing course rather than only pass examination. } \\
\hline \multirow[t]{2}{*}{ experimental class } & $0 \%$ & $8.8 \%$ & $8.8 \%$ & $50 \%$ & $32.3 \%$ \\
\hline & \multicolumn{5}{|c|}{ 7. I am very confident in my Business English Writing ability. } \\
\hline \multirow[t]{2}{*}{ experimental class } & $0 \%$ & $11.8 \%$ & $5.9 \%$ & $47.1 \%$ & $35.3 \%$ \\
\hline & \multicolumn{5}{|c|}{$\begin{array}{l}\text { 8. In Business English Writing class, I have enough material and know how to organize a } \\
\text { composition by exchanging ideas with my classmates. }\end{array}$} \\
\hline \multirow[t]{2}{*}{ experimental class } & $0 \%$ & $5.9 \%$ & $17.6 \%$ & $47.1 \%$ & $29.4 \%$ \\
\hline & \multicolumn{5}{|c|}{ 9. I think the writing approach the teacher used is very interesting. } \\
\hline \multirow[t]{2}{*}{ experimental class } & $0 \%$ & $0 \%$ & $8.8 \%$ & $53 \%$ & $38.2 \%$ \\
\hline & \multicolumn{5}{|c|}{ 10. I think I can improve my Business English Writing abilities gradually. } \\
\hline \multirow[t]{2}{*}{ experimental class } & $0 \%$ & $0 \%$ & $5.9 \%$ & $41.2 \%$ & $53 \%$ \\
\hline & \multicolumn{5}{|c|}{ 11. I think the writing approach that the teacher is taking can improve my creative ability. } \\
\hline \multirow[t]{2}{*}{ experimental class } & $0 \%$ & $5.9 \%$ & $17.6 \%$ & $47.1 \%$ & $29.4 \%$ \\
\hline & \multicolumn{5}{|c|}{ 12. I think the writing approach that the teacher is taking can improve my investigation ability. } \\
\hline experimental class & $0 \%$ & $0 \%$ & $8.8 \%$ & $50 \%$ & $41.2 \%$ \\
\hline
\end{tabular}

e. Interview

To further understand student's attitude toward comprehensive ladder task chain model, after the experiment, the researcher randomly choose 6 students from the experimental class to carry on the semi-structured interview at students' will. 1) Do you like the teaching method used in the business English writing class this semester? Why? 2) Do you like the pre-task activity? Do you think it helpful? 3) What is your favorite task model? 4) Do you like group discussion? Do you have any suggestions for improving the effective cooperation in group? 5) Do you think you are active in this semester's business English writing class? Student's reply is recorded and organized according to the order of questions. The qualitative data analysis of the interview shows that the students have accepted the comprehensive ladder task chain model and express positive affirmation for the teaching activities. Students are active in the class and effectively enhance their learning interest. Some students think some students spend too much time and some contribute a little.

\section{Conclusion}

The comprehensive ladder task chain model has provided a feasible teaching method for the independent college students, which helps to bring the students' autonomic learning ability and team spirit into play. [5] This pattern is not isolated, since it has absorbed the 3P and Williams' model and has made improvement. Teachers should make adjustments to this model according to different learning environment and student' levels so as to have the best effect. The comprehensive ladder task chain model still has much research space and how to balance the development of business English writing and oral business English, how to balance the development of business English writing and business English reading and how to apply it to other business class will be the concern of the future study. 


\section{Acknowledgement}

In this paper, the research was sponsored by the Key Teaching Research Project of Colonel-level Huaxia Institute of Technology, or Wuhan University of Technology Huaxia College (Project No. 1510) and the title of the project is On the Applied Research of the Task-based Teaching Approach in Business English Writing Courses.

\section{References}

[1]Nunan D. Designing Tasks for the Communicative Classroom. [M] .Cambridge: Cambridge University Press, 1988:37.

[2] Designing Tasks for the Communicative Classroom [M].Cambridge: Cambridge University Press, 1989:19.

[3] Ruan Jizhi. On business writing class design and teaching model [J]. Shandong Foreign Language Teaching, 2005.

[4] Sara Cushing Weigle,Keisha Parker. Source text borrowing in an integrated reading/writing assessment[J]. Journal of Second Language Writing. 2012 (2)

[5] John Bitchener. Evidence in support of written corrective feedback[J]. Journal of Second Language Writing. 2007 (2) 